\title{
Legal Education And Challenges Of Contemporary Developments In Nigeria
}

\section{Dr Bagoni A. Bukar, Ll.B (Hons.), B.L, Ll.M, Ph.D}

Email Address: Bagonibukar@,Gmail.Com; Babagonibukar@,Yahoo.Co.Uk

The author is a Reader in Law and the Head, Department of Private Law, University of Maiduguri.

He is also part of the Law firm of Bukar \& Co. a law firm that engages in general practice with bias in corporate law/international commercial arbitration. Dr Bukar has 25 years experience of teaching and practicing law. He has over 25 published articles in both local and international journals and has also attended and presented papers at international conferences.

\section{ABSTRACT}

The development of any society is anchored on the existence of enabling environment for imparting legal education. Technological breakthrough and globalization among other things has made the provision of sound legal education to would-be lawyers and continuing legal education for lawyers, judges and academics a sine qua non at national and international levels. Hitherto, legal education was and unfortunately is still to a large extent restricted to the domain of domestic law sufficient enough to give a student broad general knowledge and exposure to other disciplines in the process of acquiring legal education. Such system of legal education which exists to date hardly if at all expose the student or the lawyer to challenges and the developments in other jurisdictions or in the emerging fields of law. A lawyer or a judge is a mirror of the system of legal education that produced him. Sadly, the laws regulating legal education, apart from being obsolete are in some cases conflicting due to the roles assigned to different and disparate organs. 


\section{INTRODUCTION}

The history of the western form of legal education in Nigeria started with the report of the Unsworth Committee on Higher Education which recommended inter alia the following:

1. Nigeria should establish its own system of legal education

2.A law school, to be known as the Nigerian Law School, be established in Lagos to provide vocational training to legal practitioners as barristers and solicitors;

3. The qualification for admission to legal practice in Nigeria should be a degree in law of any University whose course is recognised by the Council of Legal Education (CLE), and the vocational course as prescribed by the Council;

4. A Council of Legal Education should be established ${ }^{1}$.

These and other recommendations of the Committee culminated in the establishment of Council of Legal Education and the Nigerian Law School for the purposes of providing vocational training of legal practitioners as barristers and solicitors. ${ }^{2}$

The academic component of legal education is undertaken by accredited faculties of law whose course of legal studies is approved by the Council as sufficient qualification for admission into the Nigerian Law School.

The National Universities Commission (NUC) on the other hand is charged with the responsibility of advising the Federal and State Governments on all aspects of university education, in particular, it sets the minimum academic standards for all degree and postgraduate programmes including those of $\mathrm{Law}^{3}$, while the general control of the conduct of matriculation examinations and determining the matriculation requirements for entry into degree progmmes in law and other disciples is undertaken by the Joint Admissions and Matriculation Board ${ }^{4}$ (JAMB).

Over the years, the Council of Legal Education Act and National Universities Commission Act had respectively undergone amendments; ${ }^{5}$ unfortunately, these amendments have done very little in the area of teaching pedagogy and course contents both at the academic and vocational levels. For instance, not much was done towards the introduction of courses in emerging fields of law and adoption of new teaching methods especially those engendered by Information and Communications Technologies (ICT). It is therefore not surprising to find the same course content

1 See the Report of the Committee on the Future of the Nigerian Legal Profession.(Lagos, Federal Government Press, 1959) cited from Problem of Legal Education by Ho. Justice M. O. Onalaja http://www.alimiandco.com/ publications.

2 See section 1(2) of the Legal Education Act 1962 now repealed by the Legal Education (Consolidation, etc.) Act, Cap.L10 Laws of the Federation of Nigeria,(LFN)

3 Section 4 National Universities Commission Act, Cap.N81 (LFN)2004

4 See section 5(1)(a) of the Joint Admissions and Matriculation Board Act, Cap. J1 (LFN). Note : Only universities offer Law degrees. Other degree awarding institutions other than universities cannot run degree programmes in law.

5 See the Legal Education Act No.12 of 1962 ; the Legal Education( Pensions) Act No.34 of 1965; the Legal Education (Amendment)Act, No.62 of 1970; the Legal Education (Amendment) Act, No.37 of 1973; the Legal Education (Amendment) No.37of 1970 (all repealed).note that the amendments were not substantial enough to radically chance the course of legal education; also see the National Universities Commission(Amendment) Act, No.10 of 1993; Cap.C 23 Laws of the Federation of Nigeria,2004 
being taught for decades without being revised and law teachers adopting the 'nail and hammer' approach to the teaching of law. However, with the introduction of clinical legal education in some universities, the foundation for purposeful and practically oriented system of legal education hitherto not contemplated by the National Universities Commission and perhaps the Council of Legal Education may well be underway.

The aim of this article is to examine the respective roles of these various organs vested with the responsibilities of shaping the course of academic and vocational legal education in Nigeria.

\section{THE ROLE OF THE NATIONAL UNIVERSITIES COMMISSION IN LEGAL EDUCATION}

The National Universities Commission is saddled with the responsibilities of among other things setting benchmark minimum academic standards and accrediting degree and other academic programmes in Nigerian universities. In pursuance of its mandate under sections 4 and 18 of National Universities Commission Act and Education (National Minimum Standards and Establishment of Institutions) $\mathrm{Act}^{6}$ and in consultation with universities, the National Universities Commission revised the Minimum Academic Standards (MAS) 1989 by updating and replacing it with the Benchmark Minimum Academic Standards (BMAS) for all courses including law. ${ }^{7}$ One of the reasons for the review of the Minimum Academic Standards in the words of the Commission is to meet up with "The impact of Information and Communications Technologies on teaching and learning and the competitiveness engendered by globalization..."8

One of the functions of the Academic Standards Department of the National Universities Commission is to among other things periodically review courses and curriculum of approved programmes in Nigerian Universities. A cursory look at the courses in the Commission's BMAS and its predecessor, the Minimum Academic Standard (MAS) 1989, reveals that the course content for both optional and compulsory law courses to a great extent remain the same. Apart from the traditional or core subjects which are compulsory for all undergraduates under the Minimum Academic and Benchmark Minimum Academic Standards, namely constitutional law, law of contract, criminal law, company law, commercial law, law of equity and trust, law of evidence, jurisprudence, land law, Nigerian legal system, law of torts and a compulsory final year project, it does appear that no effort is being made by the National Universities Commission and universities to revise the law curriculum to meet the current needs of the student in a rapidly changing society. If the aim of the periodic curriculum review as stated in the Bench Mark Academic Standards document is to bring the law programme in line with the changing society ${ }^{9}$, then this is perhaps the most appropriate time to make subjects such as international human rights law, international environmental law, cyber and internet law, law on internal displacement, genocide and war crimes, e-commerce and a host of others compulsory. If the student is not exposed to these areas of law

6 Cap. N81 and E3 Laws of the Federation of Nigeria, (LFN),2004

7 See National Universities Commission, Benchmark Minimum Academic Standards(NUC BMAS) for Undergraduate Programmes(Law) in Nigerian Universities, April, 2007, p.1 http://www.nuc.edu.ng/nucsite/file/ DASS/BMAS\%20Law.pdf visited 13/05/13.

8 Ibid.

9 See NUC BMAS op.cit para.1.5.5.2 at p.9 which requires curriculum review after every five years. This therefore means the BMAS 2007 is due for review. 
at the undergraduate level, then it may be too late in the day to educate him on same through continuing legal education or through other ad hoc means. Consequently, the student may be handicapped in diagnosing legal issues or in rendering informed legal opinion or even to take appropriate legal action when confronted with challenges in those areas. He therefore becomes dependent on international organizations, such as Amnesty International, Human Rights Watch, Earth's Rights International and foreign governments for reports of violations taking place in his backyard. If the Commission cannot add new courses in emerging fields of law to meet up with the global trends, then the course content should at least be reviewed to include for example some aspects in e-commerce which can conveniently be subsumed under commercial law, contract and company law, while genocide and war crimes can be taught as part of international criminal law. In addition, a fair knowledge of basic aspects of other legal systems of the world and jurisprudence of some commonwealth countries should be introduced in order to assist in the development of intellectual capacities of students and to further make them understand and better appreciate their immediate legal environments as well as those of others. This could be one of the reasons why the BMAS document requires library holdings of faculties of law of Nigerian universities to include standard precedent books, such as Encyclopedia of Forms and Precedents, Black's Law Dictionary and law reports from English, American, Australian, Indian, Kenyan and Canadian jurisdictions. Such law reports include Australian Commonwealth Law Reports, Canadian Dominion Law Report, Indian Law Reports and the East African Law Reports. The inclusion of these law reports and standard works in the field of law from these countries is to enable the student have some idea of the working of the law in other jurisdictions with whom we share some similarities and/ or differences. In this age where action of nations is increasingly judged by international legal standards, there is no reason for limiting the law student's horizon to domestic law alone, hence, the need to update and expand the law curriculum to include jurisprudence of other nations and international law.

The faculties of law in conjunction with their respective universities must take the lead in reshaping legal education curricula by putting forward proposals to the appropriate organs for reform.

\section{COUNCIL OF LEGAL EDUCATION}

The mandate of the National Universities Commission include among others giving approval for the establishment of faculties, academic units etc. ${ }^{10}$ in Nigerian universities. The Council of Legal Education on the other hand has the responsibility for the legal education of persons seeking to become members of the legal profession. ${ }^{11}$ To this end, the Council is empowered to issue a qualifying certificate to a person which when issued, signifies the successful completion of a course of practical training in the Nigerian Law School and is eligible for call to the Nigerian Bar. Such persons seeking to become members of the legal profession must however, among other requirements, possess a university law degree whose course for the degree is recognized by the Council. It should be noted that the accreditation of a law degree progamme by the NUC does not automatically translate into its accreditation or recognition by the Council of Legal

10 see s4(1)(b)(iii) Cap.N81 op.cit

11 Section 1 (2) of the Legal Education Consolidation etc.) Act. Op.cit 
Education. ${ }^{12}$ This probably explains why there is a clamour for the amendment of the Council of Legal Education Act, so as to give the Council of Legal Education some measure of control over academic programmes (Law) in Nigerian universities. As it is, there is no legal obligation on the part of the Commission to consult the Council in approving the establishment of any faculty of law. Although such a faculty when established must also satisfy the Council's minimum requirement in terms of curriculum and facilities before it is accredited.

Thus, while the Commission has the power to approve establishment of new faculties and accreditation of existence ones based on its parameters, the Council equally has the power to deny accreditation of the same programme approved by the Commission based on its own parameters too.

It may be observed that the National Universities Commission has on its board a person representing law as a discipline, ${ }^{13}$ there is however no corresponding provision for representation of the National Universities Commission on the Council of Legal Education. ${ }^{14}$ Consequently, there is bound to be conflict in the approach of these two organs to matters relating approval of programmes. The absence of representation of the National Universities Commission on the Council is indeed a serious flaw. The National Universities Commission being a major stakeholder in legal education is robbed of the advantage of contributing to matters that may have bearing to its area of competence at the Council's regular meetings. There is the need for the Council of Legal Education to involve the National Universities Commission in for instance, its accreditation visits in the same way the Commission does when constituting accreditation exercises for law programmes in Nigerian universities. ${ }^{15}$

The roles of the Commission and Council in Legal education is not mutually exclusive, though they are separate and independent bodies; yet, both are dependent on each other. Therefore, these two bodies and indeed the Nigerian Bar Association have the responsibility of co-operating with one another so as to meet up with the challenges facing legal education. The Council of Legal Education, the National Universities Commission and indeed all other stakeholders in the business of legal education must therefore be on the same page for this purpose.

\section{THE ROLE OF THE NIGERIAN BAR ASSOCIATION IN LEGAL EDUCATION}

The Nigerian Bar Association (NBA) is the umbrella body for all lawyers in Nigeria. Unlike the American Bar Association, the Nigerian Bar Association has no direct statutory role in the scheme of legal education. However, all members of the Council of Legal Education are legal practitioners who invariably are members of the NBA. Sixteen members of the Council including the President

12 The Council for Legal Education has refused to accredit the Law degree progamme of the National Open University of Nigeria(NOUN) for failing to meet up with its benchmark requirements for law degree, see, Thisday newspaper, $10^{\text {th }}$ April, 2013,http:www.thisdaylive.com

13 See section 2 (d)(viii) Cap.N 81 op.cit. for the composition of the National Universities Commission.

14 Section 2(1), ibid

15 External and Internal Quality Assurance: Imperatives for the development of Nigerian University System: A paper presented at the Workshop on Quality Assurance and Service Delivery in Nigerian Universities, held at the University of Maiduguri from $4^{\text {th }}-6^{\text {th }}$ June, 2013 by Dr N.B Saliu, Deputy Director (Undergraduate/ Institutional Accreditation) National Universities Commission) Abuja, 
of the NBA are selected or elected to represent the NBA, the President being a member by virtue of his office ${ }^{16}$. Considering the rich and varied composition of the Council - (lawyers in practice, members of the NBA, Attorney-General of states and all Deans of the Faculties of Law) among others, one may be tempted to conclude that the Council is in a better position than the National Universities Commission to bring about the desired change in legal education. Unfortunately, the Legal Education (Consolidation Act) is neither flexible enough nor gives room for change in legal education as is desired unless the same is amended or repealed and replaced with an all encompassing one. For now, the NBA is trying to face the challenges of legal education through its progamme of Continuing Professional Development (CPD) ${ }^{17}$ The Continuing Professional Development programme which is an aspect of legal education include:

a) the attendance and participation in accredited courses

b) lectures, seminars, workshops and conferences on law approved by the NBA.

c) writing on the law and its practice in books, journals or newspapers approved by the NBA

d) Study towards professional qualification approved by the NBA.

e) other approved means of acquiring legal professional knowledge and experience.

The aim of the CPD is to continuously improve the quality of legal education by keeping the lawyer abreast of developments professionally and in academic terms.

As observed earlier, a lawyer is a reflection, a mirror of the system of legal education that produced him - a good system of legal education produces better equipped lawyers. Likewise, a system of legal education can make its product better through continuing legal education as is the case with the CPD of the NBA. The judicial arm is similarly facing the challenges of legal education through its programme of Continuing Judicial Education, a progamme carried out by the National Judicial Institute (NJI). The NJI performs tasks similar to that of CPD by conducting trainings, courses, organising seminars, conferences and workshops for judicial officers often based on need assessment. These forms of continuing legal education will no doubt enhance the quality of the recipients in particular and the system in general. ${ }^{18}$

\section{CHALLENGES OF LEGAL EDUCATION}

The philosophy and objective behind the Law degree programme (LL.B) as enunciated by the NUC is:-

"... to ensure that the graduate of Law will have good general knowledge of Law, including a clear understanding of the place and importance of Law in society...It is therefore necessary that the student of Law should also have a broad general knowledge and exposure to other disciplines in the process of acquiring legal education. The programme should introduce students to the general knowledge in Law, acquaint them with principles of judicial process and legal development, and equip them with the basic tools of legal

16 Section 2 NUC Act, op.cit for composition of the Council

17 Section 11(1) 2007, made pursuant to the Legal Practitioners Act, Cap. Cap.L11, laws of the Federation of Nigeria,2004

18 Hon. Justice Dahiru Mustapher (former Chief Justice of Nigeria), Contemporary Problems Plaguing Judicial Educators: Experience and Way Forward for National Judicial Institute, Nigeria, NJI Law Journal (2012)Vol.7 pp1-14. 
analysis and methods. Legal education should act first, as a stimulus to stir the student into critical analysis and examination of the prevailing social, economic and political systems of his community and, secondly, as an intellectual exercise aimed at studying and assessing the operation, efficacy and relevance of various rules of Law in the society. The curriculum must also ensure that Law is taught as it exists at any given moment, and that every Law student will be comparative in his approach to legal studies bearing in mind that there are many systems of Law (Statutory Law, Common law, Customary Law and Islamic Law) currently in operation."

This philosophy underpinning the LL.B law pragramme may satisfy the academic requirements of a law student who desires to be content with being acquainted with general principles of law and legal conditions of his immediate environment. However, in vocational terms, a law student needs to go much further in order to actualize his dream of becoming a 21 st century lawyer. It is partly in realization of this fact that the idea of clinical legal education was conceived.

The aims of clinical legal education include among other things the provision of necessary skills to would-be lawyers by exposing them to practical aspects of law at an 'impressionable stage'. The question is has the introduction of clinical legal education achieved its purpose. While we do not have any statistics to justify any stand we may take on this poser, one fact however stands out, most of those who teach courses on clinical legal education do not have the necessary skills in the areas being taught. If we agree that the aim of clinical legal education is designed to equip the student with tools and skills necessary for a would-be lawyer to acquire practical skills, then, the teacher must himself be acquainted with the nifty side of practice both as a solicitor and advocate. This means that the teacher must as a matter of necessity be well grounded in the general practice of the law. Regrettably, there are not enough practically oriented law teachers to take the students through the most critical aspects of legal education. In order to succeed in meeting the challenges of clinical legal education, the teacher must as a matter of necessity have the necessary skills and experience in advocacy and solicitors work before imparting it to others. As rightly observed by the then Chief Justice of the United States, Justice Burger ${ }^{19}$ :

"...The medical profession does not try to teach surgery simply with the books; more than 80 percent of all medical teaching is done by practicing physicians and surgeons. Similarly, trial advocacy must be learned from trial advocates".

The above statement is apt when it comes to clinical legal education and the vocational training at the Nigerian Law School. It will therefore be foolhardy to expect law students to learn the necessary advocacy and other skills from those who do not have them. Clinical education must go beyond teaching with the books. The amendment to the Legal Aid Council Act ${ }^{20}$ which recognizes University Law Clinics as centers for provision of legal aid, presuppose the existence of trial advocates who can represent those eligible to legal aid in accordance with the Legal Aid (amendment) Act. Otherwise how else can the lecturer/ clinician render legal assistance to the indigent or those on remand without bail for minor offences? This then brings us to experiential legal education which is what the law clinic and the law school should be involved in for the most part of the students' training.

19 Burger, The Special Skills of Advocacy: Are Specialized Training and Certification of Advocates Essential to our System of Justice? 42 FORDHARM L. REV. 227 (1973) at 232

20 See Legal Aid (Amendment) Act,2011 
The Nigerian Law School as a vocational and skill acquisition center has sadly abdicated its responsibilities of giving practical approach to legal training in favour of a three-month period of court and law office attachment. This may perhaps be the reason for the call for restructuring and reorganization of the Council of Legal Education and the Nigerian Law School and by implication a call for the review of the Legal Education (Consolidation etc) Act as well as other laws on legal education. Among those making such calls is the Chairman of the Council of Legal Education who is reported to have remarked as follows:

"It must be noted that the proposals, for restructuring and re-organisation of the Council of Legal Education and the Nigerian Law School, are geared towards improving the content and quality of the Legal Education in Nigeria, and ensure that the legal practitioners produced by the Nigerian Law School are duly equipped with requisite character and learning, so that they may be better enabled to discharge their duties and responsibilities in that regard, not just in Nigeria, but throughout the world."21

Any proposal for restructuring or review of legal education must entail substantial amendment or even the outright repeal of the Legal Education Act. Lack of review of laws governing legal education is one of the major challenges confronting legal education in Nigeria. Other challenges which also need to be addressed include the dearth of legal materials and the limited exposure of law teachers to workshops and conference.

\section{OVERCOMING THE CHALLENGES}

In order to overcome the challenges of legal education, the academic and vocational curriculum has to be redesigned to make it more relevant to the contemporary needs of the student and the society. Times are changing; therefore, the teaching of Law must change with the tide otherwise the profession will soon be inundated with impostors who cannot easily be distinguished from the lawyer due to poor academic and vocational training. Vocational training should in particular be made more practical by attaching law students to law firms and courts for at least seven of the nine month period of the academic session. My experience over the years as a law teacher and practitioner is that law office attachments afford the average student the opportunity of acquiring necessary skills faster than he does with the theoretical aspect. Unfortunately, the period allocated for the law office and court attachment is not enough for any meaningful acquisition of vocational education.

At the academic level, law libraries should be better equipped with enough up to date legal materials with access to legal resources and all the information communication technology (ICT). The teaching of clinical legal education courses should be expanded, streamlined and made compulsory for all law students. In addition, law clinics should establish linkages with law firms so as to enable the student to have early exposure to experiential legal education by following lawyers to court and getting involved in the management of the law office among others. This way, the student will start learning the 'tricks' of the trade. Most importantly, if vocational education is to remain wholly a government enterprise, then there is the need to harmonise the roles of the Council of Legal Education and the National Universities Commission under a single legislation on legal education. This is to avoid duplication and conflict in the roles of National Universities

21 Thisday Newspaper, April,10,2013, 
Commission and the Council over accreditation, curriculum development etc.

On the other hand, if the law school is to be run by the faculties of law of the various universities as is being advocated recently, a view which I also subscribe to, then activities of law clinics should be streamlined and the same should be made the nucleus of university law schools. Allowing some selected universities to begin the law school programme will assist in reducing the heavy backload of applicants who for one reason or the other could not be admitted to the Nigerian Law School.

It may well be remembered that the raison d'etre for increasing the number of Law school campuses from four to six in the last two years is to allow the ever growing population of law graduates fulfill their dreams of becoming lawyers. The same argument can be extended in allowing some universities to run the law school programme with the ultimate aim of divesting the Nigerian Law School of functions of providing legal education to persons seeking to become members of the legal profession in the long run since it has become obvious that the Nigerian Law School cannot cope with the ever increasing number of applicants. When this happens, the Council of Legal Education will remain the central examination body for all the law schools while at the same time retaining its power of issuing qualifying certificates to those entitle to be called to Bar.

\section{CONCLUSION}

Legal education is at a cross road, it is currently facing challenges which I believe are not insurmountable. As it is, the Legal Education (Consolidation etc.) Act allows only the federal government to establish and run law school. While the establishment and running of universities including faculties of law in those universities is open to all and sundry. Out of the 128 universities in Nigeria, 40 are owned by the federal government, 38 by state governments and 50 are privately owned. And of this number, thirty six run degree programes in law with prospect for more. There is however only one Nigerian Law School with six campuses owned and funded by the federal government that admits candidates for practical training from all the thirty six faculties of law and law graduates of foreign universities. The Nigerian Law School cannot cope with the increasing number of applicants. Hence, the need for universities to run their own law schools. If practical training at the Nigerian Law School is the three-month court and law office attachment, then law clinics can equally organize and better supervise the students in that respect.

Finally, whether the Nigerian Law School remains as it is or the faculties of law of Nigerian universities are allowed to run law school programmes as is being advocated, the curriculum of legal education must be restructured. Commerce is not only about trade in goods but it is also about trade in services, in order for the Nigerian trained lawyer to be able to compete globally, the education curriculum must be made competitive, purposeful and result oriented. 
